\title{
John Dewey: lugares e experiências em pares
}

John Dewey: Places and Experiences in Pairs

John Dewey: lugares y experiencias en pares

\section{Mirian Celeste Martins ${ }^{1}$}

\section{Renata Queiroz de Moraes Americano ${ }^{2}$}

\section{Mário Fernandes Ramires ${ }^{3}$}

1 Pesquisadora e arte/educadora do Programa de Pós-graduação em Educação, Arte e História da Cultura e do Curso de Pedagogia na Universidade Presbiteriana Mackenzie onde coordena os Grupos de Pesquisa: Arte na Pedagogia/GPAP) e Mediação cultural: contaminações e provocações estéticas/GPeMC. Membro do Conselho Mundial para América Latina da InSEA - Internationa Society of Education through Art. Foi professora do Instituto de Artes/Unesp. Publicou livros e inúmeros artigos. Tem formação em Artes Visuais com doutorado pela Faculdade de Educação/USP (1999) e mestrado pela Escola de Comunicações e Artes - ECA/USP (1992).www.mirianceleste.com.br; mcmart@uol.com.br

2 Pedagoga, pesquisadora, assessora pedagógica do Acaia Pantanal/MS, integrante do educativo da Casa Lebre em Bragança Paulista/SP. Mestra em Educação, Arte, História e Cultura e doutoranda do mesmo programa na Universidade Mackenzie. Pós-graduada em Gestão e Currículo pelo Instituto Singularidades. Pesquisadora do GPAP e do Projeto de Extensão Ambiências educadoras. Na Escola Viva SP foi coordenadora e Vice-diretora Pedagógica Foi professora do curso de Pós-graduação Abordagem Educativa Reggio Emilia, de cursos de extensão e da graduação em Pedagogia do Instituto Singularidades. renataqamericano@gmail.com

3 Historiador, pedagogo, docente na educação básica, em cursos superiores de licenciatura e em cursos de pós-graduação em educação. Membro do GPAP. Mestre em História Cultural e doutorando no Programa de Pós-graduação em Educação, Arte e História da Cultura, da Universidade Presbiteriana Mackenzie, no qual desenvolve uma pesquisa sobre o uso de imagens em Trabalhos de conclusão de Curso feitos por estudantes de Pedagogia. professormariorf@gmail.com 


\section{RESUMO}

Propor experiências além dos espaços das instituições de ensino pode trazer vivências únicas e bastante significativas para estudantes e docentes, seja no Ensino Superior ou na Educação Básica. A experiência a que nos referimos aqui, conforme destacou John Dewey (2010, 1979a, 1979b, 1978), trata de maneiras de viver momentos e situações que são, ao mesmo tempo, singulares e plurais, construções coletivas de tramas de ideias e pensamentos muito além das vivências disciplinares e conteudistas presentes nos espaços escolares e nas instituições de Ensino Superior. Partindo dessas premissas, este artigo aborda momentos distintos de experiências estésicas no contexto educacional, realizadas em espaços públicos em São Paulo, com estudantes de Licenciatura em Pedagogia e Educação Física e também de um programa de pós-graduação, e no Pantanal de Mato Grosso do Sul, com educadores de uma escola das águas. A escrita do texto dialoga com pares fotográficos sob a fundamentação teórica de Ricardo Marín Viadel, Joaquin Roldán e Rafaèle Genet (2017), como um conceito advindo da a/r/tografia, que coloca os autores como criadores, professores e pesquisadores em metodologias que se baseiam na arte.

\section{PALAVRAS-CHAVE}

Experiência; John Dewey; Educação; A/r/tografia; Pares Fotográficos

\section{ABSTRACT}

Proposing experiences beyond the spaces of educational institutions can bring unique and very significant experiences for students and teachers, whether in Higher Education or Basic Education. The experience we refer to here, as highlighted by John Dewey (2010, 1979a, 1979b, 1978), deals with ways of experiencing moments and situations that are, at the same time, singular and plural, collective constructions of very webs of ideas and thoughts, in addition to the disciplinary and content experiences present in schools and higher education institutions. Based on these premises, this article approaches different moments of aesthetic experiences in the educational context, carried out in public spaces in São Paulo, with undergraduate students in Pedagogy and Physical Education and also from a graduate program, and in the Pantanal of Mato Grosso do Sul, with educators from a riverside schools. The writing of the text dialogues with photo pairs under the theoretical foundation of Ricardo Marín Viadel, Joaquin Roldán and Rafaèle Genet (2017), as a concept arising from a/r/tography, which places authors as creators, teachers and researchers in methodologies that are based in art.

\section{KEY WORDS}

Experience; John Dewey; Education; A/r/tography; Photo Pairs. 


\section{Revista Apotheke}

\section{RESUMEN}

Proponer experiencias más allá de los espacios de las instituciones educativas puede traer experiencias únicas y muy significativas para estudiantes y profesores, ya sea en Educación Superior o Educación Básica. La experiencia a la que nos referimos aquí, como destaca John Dewey (2010, 1979a, 1979b, 1978), trata de formas de experimentar momentos y situaciones que son, al mismo tiempo, singulares y plurales, construcciones colectivas de redes mismas de ideas y pensamientos, además de las experiencias disciplinarias y de contenido presentes en las escuelas e instituciones de educación superior. Con base en estas premisas, este artículo aborda diferentes momentos de experiencias estéticas en el contexto educativo, realizadas en espacios públicos de São Paulo, con estudiantes de pregrado en Pedagogía y Educación Física y también de un programa de posgrado, y en el Pantanal de Mato Grosso do Sul, con educadores de una escuela ribereña. La escritura del texto dialoga con pares fotográficos bajo el fundamento teórico de Ricardo Marín Viadel, Joaquin Roldán y Rafaèle Genet (2017), como un concepto que surge de la a/r/tografía, que coloca a los autores como creadores, docentes e investigadores en metodologías que se basan en arte.

\section{PALABRAS CLAVE}

Palabras clave: Experiencia; John Dewey; Educación; A/r/tografía; Pares Fotográficos. 


\section{Aquela experiência}

A educação, para realizar os seus fins, tanto para o indivíduo quanto para a sociedade, deve basear-se em experiência, que é sempre a experiência atual da vida de algum indivíduo. (DEWEY, 1979a, p. 95)

"Experiência atual da vida", diz Dewey! Atual ou atualizada na memória e na reflexão trazida à tona, a experiência é estésica quando traz, além da vida, o afeto e a cognição. Experiência que toca professores e estudantes mobilizados pela ação deflagradora.

O termo experiência, entretanto, traz em si uma pluralidade de sentidos, seja quando ela é produzida em laboratório, como experimento, seja nas vivências de determinadas práticas, em alguma profissão ou atividade cotidiana. As experiências se relacionam ao que "nos acontece", como diria Larrosa (2015). Observação sensível, imaginação criadora e pensamento reflexivo são operações presentes nas experiências que nos marcam.

Para Dewey, o cognitivo, o afetivo e a vida prática se entrelaçam e se movem em direção à consumação e ao término, não apenas à cessação do tempo. A consumação é antecipada pela consciência durante toda a experiência, em avaliação constante, ou, como diz Dewey: "É antecipada durante todo o processo e reiteradamente saboreada com especial intensidade" (2010, p. 138). Consciência aberta, sensível e atenta, porque percebe o que amplia, porque a transcende. Atenção não fluente ou errática, capaz de aproveitar todos os "proximais" aos seus projetos em construção. Na experiência há uma unidade de ação e consequências, há movimentos de antecipação e acumulação que levam à consumação, que já é prenhe de novos germes, de novos propósitos, pois "o tempo da consumação é também de um recomeço" (2010, p. 81). E é nesse sentido que retomamos experiências vividas, para refletir sobre elas.

Assim, o conceito de experiência está relacionado a momentos que criam marcas em nossa existência, tornando-os singulares e únicos. No caso deste trabalho, são experiências em momentos de aprendizagem com estudantes do Ensino Superior e educadores de uma escola ribeirinha do Pantanal de Mato Grosso do Sul. Estamos nos referindo a experiências singulares, tal como destacou Dewey:

A experiência singular tem uma unidade que the confere seu nome - aquela refeição, aquela tempestade, aquele rompimento de amizade. A existência dessa unidade é constituída por uma qualidade ímpar que perpassa a experiência inteira a despeito da variação das partes que a compõem. (DEWEY, 2010, p. 112)

Experiências que provocaram algumas marcas nos envolvidos, nas vivências tanto na cidade de São Paulo como no Pantanal de Mato Grosso do Sul, e alimentaram duas pesquisas de doutorado e as ações docentes dos autores. Estamos vivendo uma experiência singular inclusive na escrita deste artigo, de aprendizagens sobre imagens e a potência que elas têm enquanto elementos de uma pesquisa.

O conceito de aula-passeio, de Célestin Freinet, educador francês do início do 
século XX, e a potência do caminhar como prática estética, de Francesco Careri (2013) fundamentam as ações realizadas fora do espaço físico das instituições de ensino e compreendidas como experiências estésicas ${ }^{1}$.

[Célestin Freinet] Diariamente organizava a aula-passeio. Saíam todos juntos, passando pelas ruas estreitas da vila, parando um pouco para admirar o trabalho do marceneiro ou para ver e ouvir as marteladas fortes e firmes do ferreiro... tudo era percebido... eram momentos mágicos. A força da natureza sensibilizava cada uma das crianças de acordo com sua personalidade, sua percepção de mundo e sua curiosidade. (SAMPAIO, 1989, p. 15)

Caminhadas como instrumento estético de conhecimento, aulas-passeio proporcionadas para conectar a vida da escola com a vida real. Para teóricos como Freinet, Dewey e Paulo Freire, a escola e a vida deveriam ser uma só. As saídas do espaço escolar ou universitário ampliam as experiências e alargam os horizontes, pois, assim como Dewey (1979b, p. 199), acreditamos que a educação precisa ter como foco o alargamento da experiência em suas várias formas de aula. "Cada experiência é uma força em marcha" (DEWEY, 1979b, p. 29).

Nas ações formativas, o maior desafio é fazer com que nossos interlocutores vivam experiências verdadeiras que provoquem reflexões. $E$, neste artigo, também afetados por um pensamento reflexivo, que, segundo Dewey (1979b, p. 13), precisa ter continuamente um caráter investigativo, voltamos às experiências vividas como um recomeço, para revê-las e ampliá-las. Para isso, nos alinhamos às propostas de pesquisas educacionais baseadas em Arte, especialmente a a/r/tografia, uma premissa de investigação ligada aos conceitos de Pesquisa-ação e Pesquisa Viva, que vê com naturalidade a existência de transformações na pesquisa durante a sua realização, pois há uma ideia de movimento constante:

A a/r/tografia é uma Pesquisa Viva, um encontro construído através de compreensões, experiências e representações artísticas e textuais. Neste sentido, o sujeito e a forma de investigação estão em um estado constante de tornar-se [...]. Portanto, enquanto projetos a/r/tográficos podem começar com um ou mais problemas de pesquisa, o ato da Pesquisa Viva admite que esses problemas evolverão durante o desenvolvimento do projeto. (IRWIN, 2013, p. 28)

Nesta metodologia, as imagens, mais do que um registro, são compreendidas como ideias, e, neste caso, o desafio foi utilizar o conceito de pares fotográficos. Para Viadel, Roldán e Genet (2017), um par fotográfico são duas fotografias que constituem uma nova unidade visual. Nessa experiência, com base em duas imagens colocadas lado a lado, ambas contendo elementos conectores, cria-se uma narrativa tão potente quanto o texto escrito. Os pares fotográficos foram cuidadosamente criados a partir dos registros feitos nos momentos das experiências realizadas, sejam

1 Pelo desgaste do termo "estético", temos preferido utilizar o termo "estésico", advindo da mesma palavra em latim: aestesis. Ao contrário de "anestesia", o termo faz parte das dimensões do ensino de arte proposto pela Base Nacional Comum Curricular (2017). 
eles fotografias obtidas por estudantes ou por mediadores e propositores dessas vivências. A finalidade desses pares fotográficos é a criação de narrativas visuais, para que as experiências possam ser compreendidas por caminhos que não sejam apenas verbais.

A análise dos pares fotográficos é importante, pois possibilita a reflexão sobre as formas como as pessoas participantes das experiências registraram os locais e representaram a si mesmas. Tanto propositores e professores quanto estudantes e participantes viveram aquelas experiências e registraram, a partir de seus olhares, momentos que merecem ser guardados e, possivelmente, postados em redes sociais. Entretanto, há uma diferença especial entre as fotografias como registro e a concepção dos pares fotográficos, que não podem ser compostos por imagens que simplesmente se colocam lado a lado; é necessário que haja conexões e possibilidades de diálogos entre seus elementos e formas.

Um Par Fotográfico é uma estrutura visual muito simples, mas é, ao mesmo tempo, enormemente complexa devido à densidade de relações que se estabelecem entre os elementos visuais de cada imagem ${ }^{2}$. (VIADEL, ROLDÁN e GENET, 2017, p. 70)

Com isso, propomos reflexões sobre as experiências vividas pelas pessoas e as formas como registraram essas experiências, lançando mão da linguagem visual a partir de pares fotográficos, como uma forma de narrativa textual em diálogo com o texto escrito. Essa forma de escrita também se mostra uma experiência singular e cheia de surpresas para os autores deste texto, que estudam relações entre arte, educação, imagens e formação de professores. $\bigcirc$ uso dos pares fotográficos não é uma escolha aleatória, pois a criação de diálogos e proposições entre as imagens e entre elas e o texto escrito exigiu que imagens fossem inseridas, retiradas, redimensionadas, além do trabalho de curadoria e escolha das fotografias.

Nosso objetivo sintonizou-se com as ideias de Dewey ao propor que "todo ato investigador precisa obter que viessem a mente fatos que tornassem capaz de alcançar uma conclusão com base na evidência" (1979b, p. 22). Ou seja, tivemos sempre o cuidado de olhar para nossas ações com base nas evidências, em fatos, e não só em suposições frágeis. Demos vazão a dúvidas, assombros, surpresas e hesitações que aparecessem, movimentando nossos pensamentos e despertando desejos de investigação para encontrarmos caminhos possíveis para nossas questões, que se mostram nas três ações que aqui se apresentam.

\section{ComparTrilhar a cidade de São Paulo: entre memórias e descobertas}

2 "Un Par Fotográfico es una estructura visual muy simple, pero es, al mismo tiempo, enormemente compleja a causa de la densidad de relaciones que se establecen entre los elementos visuales de cada imagen." 
Para dar início a este tópico, propomos a análise do par fotográfico presente na Fig.1: registro feito por uma aluna do curso de Pedagogia durante uma caminhada de cerca de sete quilômetros, na trilha que leva ao topo do Núcleo Pedra Grande, localizado no Parque Estadual Serra da Cantareira, na cidade de São Paulo. O par fotográfico provoca questões: Quais são os "personagens, objetos, edifícios, obras de arte, com especial atenção para aqueles que são decisivos para o sentido do Par"? (VIADEL, ROLDÁN e GENET, 2017, p. 72). Pensemos nas formas estruturais da composição, ou seja, como os elementos principais e secundários das imagens dialogam? Como as pessoas, objetos e elementos da natureza estão em diálogo? No que diz respeito à estratégia argumentativa deste par fotográfico, ela está inserida na ideia de registro da experiência feita com e por estudantes, ocorrida fora do espaço físico da instituição de ensino. Quais ideias visuais tornam possível seu uso em pesquisas e ensino baseados em arte, nesse caso, com pares fotográficos?
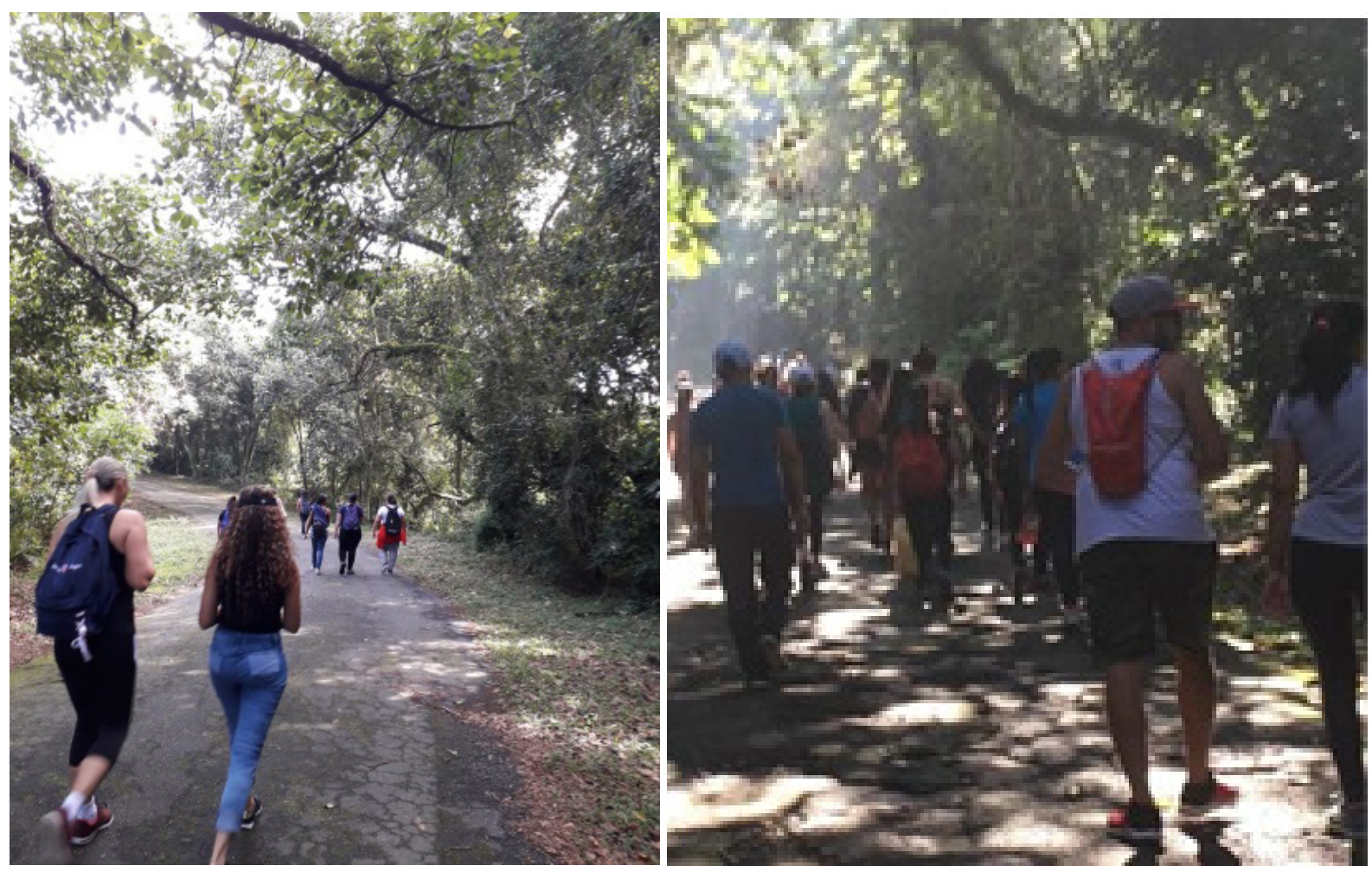

Fig. 1. Mário Fernandes Ramires (2021). Estudantes nas trilhas. Par fotográfico composto por duas fotografias de Jailda Couto de Oliveira (Estudantes na trilha 01 e Estudantes na trilha 02, 2019).

Na verdade, essas questões propostas por Viadel, Roldán e Genet (2017) podem ser critérios para a leitura de todos os pares fotográficos presentes neste artigo e, neste sentido, relacionam-se com o conceito de experiência proposto por John Dewey (2010). Se a experiência verdadeira é única, nossa escrita, ao lançar mão das imagens como narrativas, pode ser considerada uma experiência, que se espelha em uma atitude empírica que a experiência deve proporcionar por não ser rígida, nem fechada, e sim viva, com potencial expansivo, como nos ensina Dewey (1979b, p. 199). 
As vivências mais marcantes vêm à tona em nossa memória sem grande esforço. Momentos que foram marcantes são relembrados mesmo décadas depois, gerando sempre novos significados a partir do momento presente. Vivências que de alguma maneira marcaram nossas trajetórias escolares, seja em eventos especiais, como excursões, gincanas, visitas a laboratórios ou competições esportivas, seja na própria sala de aula, com trabalhos realizados em grupos, leitura de livros, avaliações, contato com docentes e colegas, entre outros. Algo que tenha nos despertado, nos surpreendido positivamente ou deixado mágoas ou frustrações. Se essas vivências são tão marcantes e significativas na Educação Básica, por que não seriam também no Ensino Superior, em cursos que formam docentes? Quais referências teóricas podemos relacionar com as práticas educacionais fora dos espaços físicos das instituições de ensino? E, principalmente, como tornar os estudantes protagonistas e proporcionar momentos de descoberta durante essas experiências?

O que trazemos aqui é a experiência singular, como foi salientado por John Dewey (2010, p. 110), na qual há uma completude: "Essa experiência é um todo e carrega em si seu caráter individualizador e sua autossuficiência. Trata-se de uma experiência". Trata-se de experiências singulares pautadas por momentos de descobertas e compartilhamento, tornadas visíveis aqui na escolha de duas fotografias da mesma estudante em duas trilhas, que podem envolver o leitor dessas imagens para ir além de sua descrição e retirar outros aspectos da experiência vivida por ela e revivida por quem criou o par fotográfico. Momentos repletos de surpresas e descobertas, vinculados ao desenvolvimento da criatividade na produção.

As surpresas também ocorreram em outras visitas, realizadas com estudantes das licenciaturas em Pedagogia e Educação Física, ao Pátio do Colégio, ao Museu Anchieta, a ruas do centro histórico da cidade de São Paulo e ao Parque Estadual Serra da Cantareira, na região Norte da mesma cidade, todas em 2019.

Cabe destacar a importância dada à arte como experiência, tanto para John Dewey (2010) quanto para Jerome Bruner (2008); ambos salientam os momentos de estudos e criação artística como verdadeiramente significativos para os seres humanos. Quando pensamos em arte, podemos considerar a própria cidade e seus monumentos como expressões artísticas. 

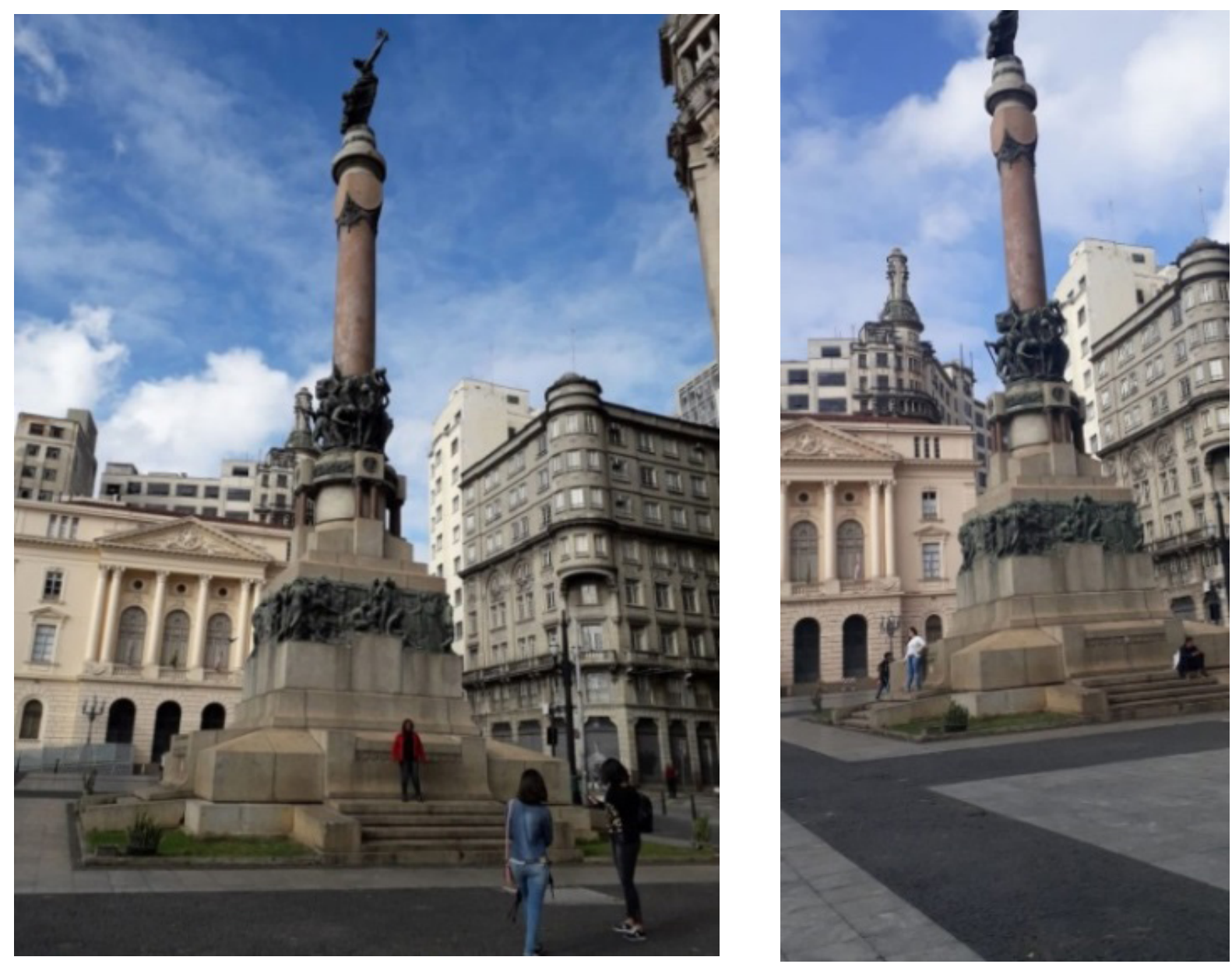

Fig. 2. Mário Fernandes Ramires (2021). Estudantes, monumento e cidade. Par fotográfico composto por duas fotografias: de Jailda Couto de Oliveira, à esquerda, Foto no monumento (2019); e de Marisa da Silva Miranda, à direita, Monumento e cidade (2019).

O Pátio do Colégio é o local onde a cidade de São Paulo foi fundada e abriga um importante acervo histórico, como o monumento Glória Imortal dos Fundadores de São Paulo, criado por Amedeu Zani, em 1925. Um par fotográfico ressalta a sua importância para os estudantes universitários e provoca discussões sobre os significados daquele monumento, porque ele está ali, quando teria sido feito, quais os símbolos ali presentes. A maioria das pessoas que participava da expedição ao centro nunca havia passado por ali ou somente em momentos de passagem, sem realmente olhar, observar seus prédios, monumentos ou pensar sobre a história da cidade e sua relação com o presente. Desde o ponto de encontro, na saída da estação de metrô São Bento, ocorreram várias observações e reflexões sobre o local, destacadamente sobre o Mosteiro São Bento. No caminho até o Museu Anchieta, conversou-se sobre quase tudo: prédios, proximidade com a Rua 25 de Março, surpresas com o local, lembranças, curiosidades; imaginou-se como aquela região teria sido no passado, como seria morar naqueles prédios antigos, que se misturavam com arquiteturas modernas, entre tantos outros aspectos. 

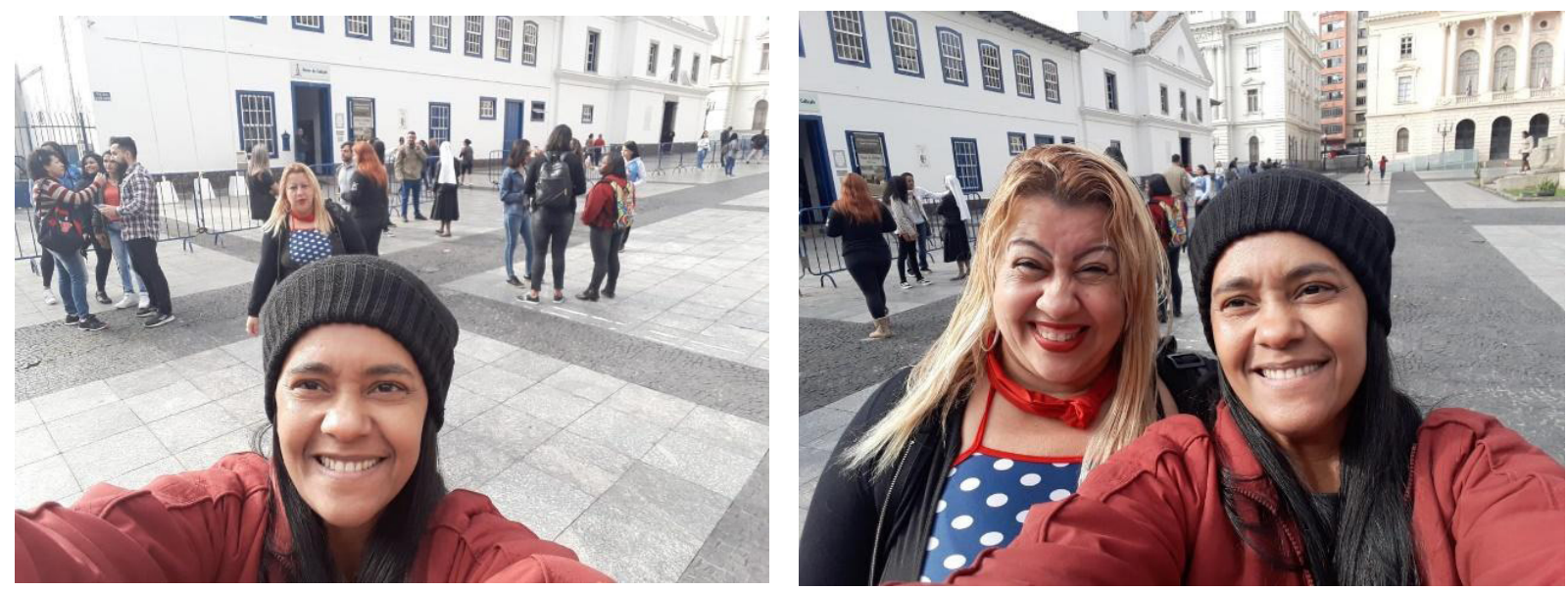

Fig. 3. Mário Fernandes Ramires (2021). Selfies na saída do Museu Anchieta. Par fotográfico composto por duas fotografias de Jailda Couto de Oliveira (2019).

Observando estes pares fotográficos, percebemos que, em uma aparente simplicidade, se revelam importantes aspectos dessas experiências. As formas como foram registradas revelam as relações entre as pessoas e delas com espaços e monumentos com os quais têm contato pela primeira vez, em uma experiência educacional fora do espaço das instituições de ensino. É preciso mirar cuidadosamente a Fig.3 para perceber o andar apressado para participar de um selfie: "Eu estive aqui, e com minha colega!", que revela a mesma intenção de Jan van Eick em sua famosa pintura $\bigcirc$ Casal Arnolfini ${ }^{3}$, pintada em 1434. $O$ par fotográfico revela a proposta de experiência feita com estudantes, as formas como eles registraram esses momentos e como esses registros fotográficos fazem parte de nossa experiência de escrita deste artigo com essa metodologia.

Em uma outra vivência, no Núcleo Pedra Grande, localizado no Parque Estadual Serra da Cantareira, o caráter interdisciplinar e até mesmo transdisciplinar foi marcante. Havia professores de História, Biologia e da área de finanças e um enorme grupo de estudantes dos cursos de Pedagogia e Educação Física com seus familiares e amigos. A primeira descoberta, ou surpresa, como diria Bruner (2008), foi saber que havia uma reserva natural tão grande como aquela em uma cidade tão urbanizada e caótica como São Paulo. Outras tramas de ideias foram se construindo nas trilhas, ao observar elementos da natureza. Entre insetos, flores, plantas, sementes, pássaros e uma pequena cobra, as trocas ocorriam a partir de lembranças, histórias de vida e ensinamentos sobre antídotos naturais, plantas venenosas, história natural da Terra, questões físicas do corpo humano, sedentarismo, prática esportiva, uma infinidade de possibilidades que transcenderam qualquer barreira imposta pelo pensamento estritamente disciplinar. Foram experiências singulares e plurais, pois estabeleceramse conexões e criaram-se diálogos a partir das observações e do compartilhamento das emoções.

3 Sobre a obra de Jan van Eick: o Casal Arnolfini, recomenda-se o vídeo disponível em: https://www. nationalgallery.org.uk/paintings/jan-van-eyck-the-arnolfini-portrait. Acesso em: 27 jun. 2021. 
Nessas experiências, cada parte sucessiva flui livremente, sem interrupção e sem vazios não preenchidos, para o que vem a seguir. Ao mesmo tempo, não há sacrifício da identidade singular das partes. Um rio, como algo distinto de um lago, flui. Mas, seu fluxo dá às suas partes sucessivas uma clareza e interesse maiores do que os existentes nas partes homogêneas de um lago. Em uma experiência, o fluxo vai de algo para algo. À medida que uma parte leva à outra e que uma parte dá continuidade ao que veio antes, cada uma ganha distinção em si. O todo duradouro se diversifica em fases sucessivas, que são ênfase de suas cores variadas. (DEWEY, 2010, p. 111)

Entender essa movimentação e essa importância dos indivíduos para formar um todo que se conecta a partir da mesma experiência é fundamental para compreender os valores dessas vivências.
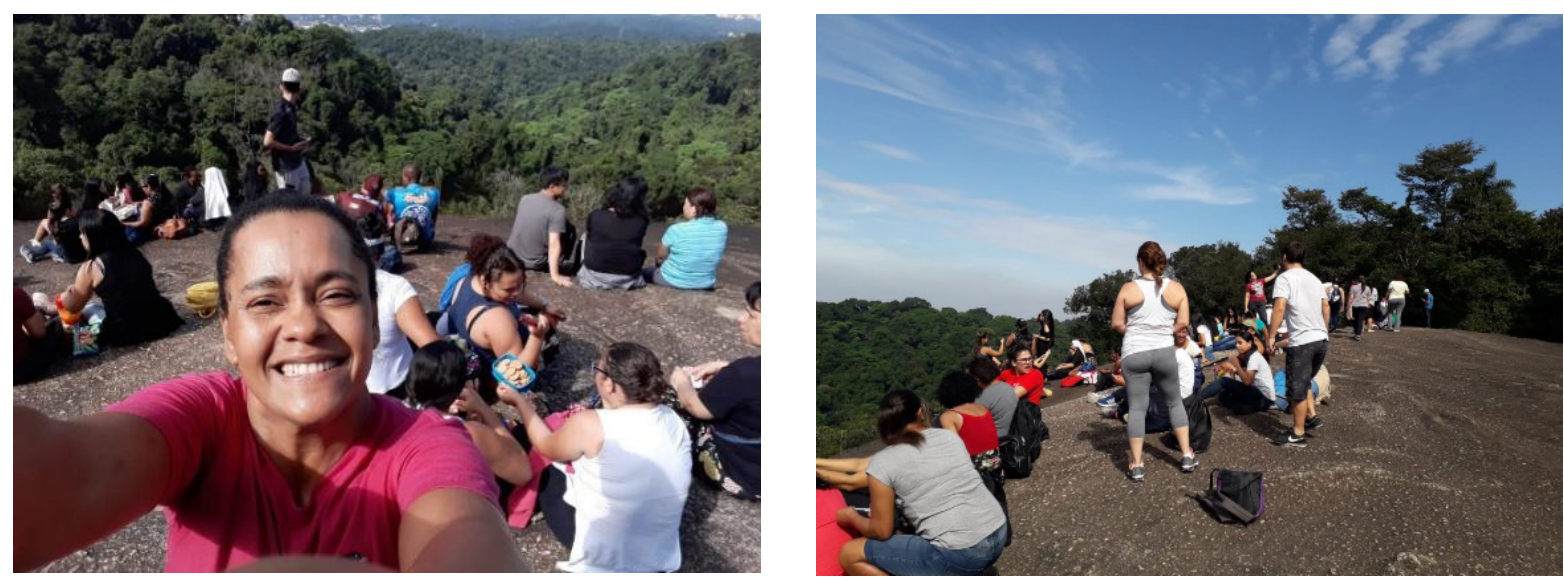

Fig. 4. Mário Fernandes Ramires (2021). Fotografias na Pedra Grande. Par fotográfico composto por duas fotografias de Jailda Couto de Oliveira, 2019.

O par fotográfico acima é composto por imagens que mostram um momento muito especial da experiência no Parque Estadual Serra da Cantareira, justamente quando o grupo chegou, aos poucos, ao final da trilha de cerca de sete quilômetros, a uma altitude de mil metros. A Serra da Cantareira era conhecida dos integrantes do grupo, pois é visível de muitas partes da cidade de São Paulo, mas as vivências e surpresas foram ressignificando a geografia e a composição da cidade de São Paulo para a maioria das pessoas e de modo afetivo, pois, chegando ao ponto mais alto da trilha, fizemos um enorme piquenique coletivo. Junto à grande pedra, com a vista aérea de grande parte da cidade e de uma imensa cobertura verde, vivenciaram-se momentos de conversa, assim como de silêncio e contemplação.

Essas experiências, cheias de surpresas afetivas, podem ocorrer tanto a partir de algo novo, inédito, como da colocação de fatos já conhecidos em novas perspectivas (BRUNER, 2008). Por exemplo, as alunas do curso de Pedagogia já haviam estudado, na disciplina História da Educação, sobre os padres da Companhia de Jesus e sua importância para a colonização por meio da educação e do aculturamento de povos indígenas. Contudo, quando estavam no Museu Anchieta, com a presença 
de uma mediadora do acervo, diante de maquetes, vestimentas dos padres jesuítas, analisando mapas, artigos do acervo de história indígena localizado na cripta do local, deparando com paredes que têm séculos de existência, obras de arte sacra, tudo isso trouxe novas perspectivas para o conteúdo abordado anteriormente na disciplina. Essas análises podem nos revelar vários elementos da cultura visual e da produção de imagens a partir de experiências únicas, conforme proposto por Dewey (2010). Perceber como uma imagem é criada em meio a uma vivência significativa, com estudantes que estão se formando para serem professores e professoras, é fundamental para entender suas relações com as imagens e a cultura visual, pois,

A cultura visual, como chave pedagógica e de pesquisa, é uma oportunidade para produzir deslocamentos, do refúgio da solidez aparente do disciplinar às inseguranças alternativas de novas explicações possíveis do que sucede em nosso entorno. (MIRANDA, 2013, p. 328)

\section{Proposições e provocações na cidade de Corumbá}

Estar no Pantanal de Mato Grosso do Sul já é, por si só, uma experiência única e singular, como define Dewey (2010). Trabalhar com os educadores de uma escola ribeirinha pertencente ao município de Corumbá, distante do centro 90 quilômetros, que são percorridos de barco, além de ser desafiador, tem provocado muitas surpresas e deixado muitas marcas. Foram vários os momentos significativos que possibilitaram observar transformações, que mobilizaram esforços tanto dos educadores como da pesquisadora, em um movimento cartográfico de natureza inventiva. Um movimento de entrelaçamento com a a/r/tografia, pela sua movimentação durante o processo e pelo uso de linguagens artísticas para provocar, analisar e desafiar pesquisadores e educadores. Criar pares fotográficos é vantajoso, em primeiro lugar, pois se trata de estruturas simples e diretas, compostas unicamente por duas imagens. Em segundo lugar, porque provocam um outro pensar sobre as experiências vividas, pois "[...] combinar duas imagens facilita o alcance de maior profundidade e complexidade de uma ideia ou argumento visual, ou então gera novas ideias inesperadas que surgem da justaposição de imagens "4 (VIADEL, ROLDÁN e GENET, 2017, p. 71). A metodologia nos colocou em um estado de experiência ao ter que investigar de um modo não habitual. Olhar para as imagens não apenas pelo conteúdo, mas entender o que as formas dão a ver.

No que diz respeito à experiência realizada no Pantanal do Mato Grosso do Sul, a escola em questão atende aos filhos da população ribeirinha do rio Paraguai, oferecendo Ensino Infantil e Fundamental, com classes seriadas até $\circ 5^{\circ}$ ano, a uma população que mora em lugares mais isolados, com praticamente nenhum

4 "[...] combinar dos imágenes facilita lograr mayor profundidad y complexidad de una ideia o argumento visual, o bien genera nuevas ideas inesperadas que surgen de la yuxtaposición de imágenes." 
acesso aos serviços públicos essenciais. Uma escola isolada no meio do rio, com muitas particularidades, demanda o desenvolvimento de metodologias próprias para proporcionar uma aprendizagem significativa para suas crianças. Como Anísio Teixeira, entendemos que método "é o modo pelo qual a experiência se processa" (1978, p. 32). Para que a equipe compreenda os métodos da escola, a formação é muito valorizada, o que tem garantido vários momentos com esse propósito em sua rotina semanal. Em especial para a equipe pedagógica, que é composta por professores, residentes, estagiários, monitores, coordenador e assessores.

Uma das questões que nos desafiam é a de ampliar o conceito de aula e do que entendemos por educação. Percebemos que, muitas vezes, as aulas são atividades isoladas que ficam centradas no professor, acontecem num horário determinado no espaço da sala e não se conectam com nada além do conteúdo de sua disciplina. Entendemos que a aula deve ser mais do que isso, podendo acontecer em diferentes espaços, conectar várias disciplinas, dar sentido à vida fora da escola, em um tempo mais flexível. A aula deve alargar as possibilidades dos alunos, dando espaço de interação, aguçando sua vontade de querer saber mais, de investigar para que de fato possam acontecer aprendizagens que modifiquem suas estruturas cognitivas. Portanto, os professores precisam pensar em como organizar esse momento para que os estudantes façam as conexões e relações dos conteúdos de maneira consistente, que considerem vários espaços, tempos e formas.

As situações de aprendizagem precisam favorecer os processos de reconstruçãoe reorganização de experiências, que, segundo Anísio Teixeira (1978, p. 17), para Dewey caracteriza o que é educação: uma manifestação relacionada à vida. Entendemos que o estudo do meio, atividade realizada anualmente, propicia esses processos. É uma proposta interdisciplinar, que escolhe focos diferentes para cada ano escolar, instigando a pesquisa e as descobertas. Cada turma desenvolve, ao longo do ano, um projeto que abarca vários conteúdos de diferentes disciplinas. Durante o dia da saída, as crianças se preparam para observar, registrar, pesquisar, perguntar, experimentar, enfim, mergulhar em descobertas sobre o ambiente e tudo que o cerca.

Uma aula-passeio, como denominava Freinet (apud SAMPAIO, 1989), uma aula caminhante, na proposição de Careri (2013), uma experiência a ser vivida com os professores na cidade de Corumbá, onde moram e andam no seu dia a dia, mas que nem sempre é observada com olhos de turista, de pesquisador, de estudante, um olhar com várias lentes e filtros diferentes. Foram feitas propostas para ampliar a relação que tinham com a cidade, de modo que descobrissem novas conexões, usassem algumas linguagens artísticas como aberturas para novas formas de ver e registrar e para que os educadores pudessem perceber suas possibilidades de expressão e investigação ao se relacionarem com as experiências propostas. 

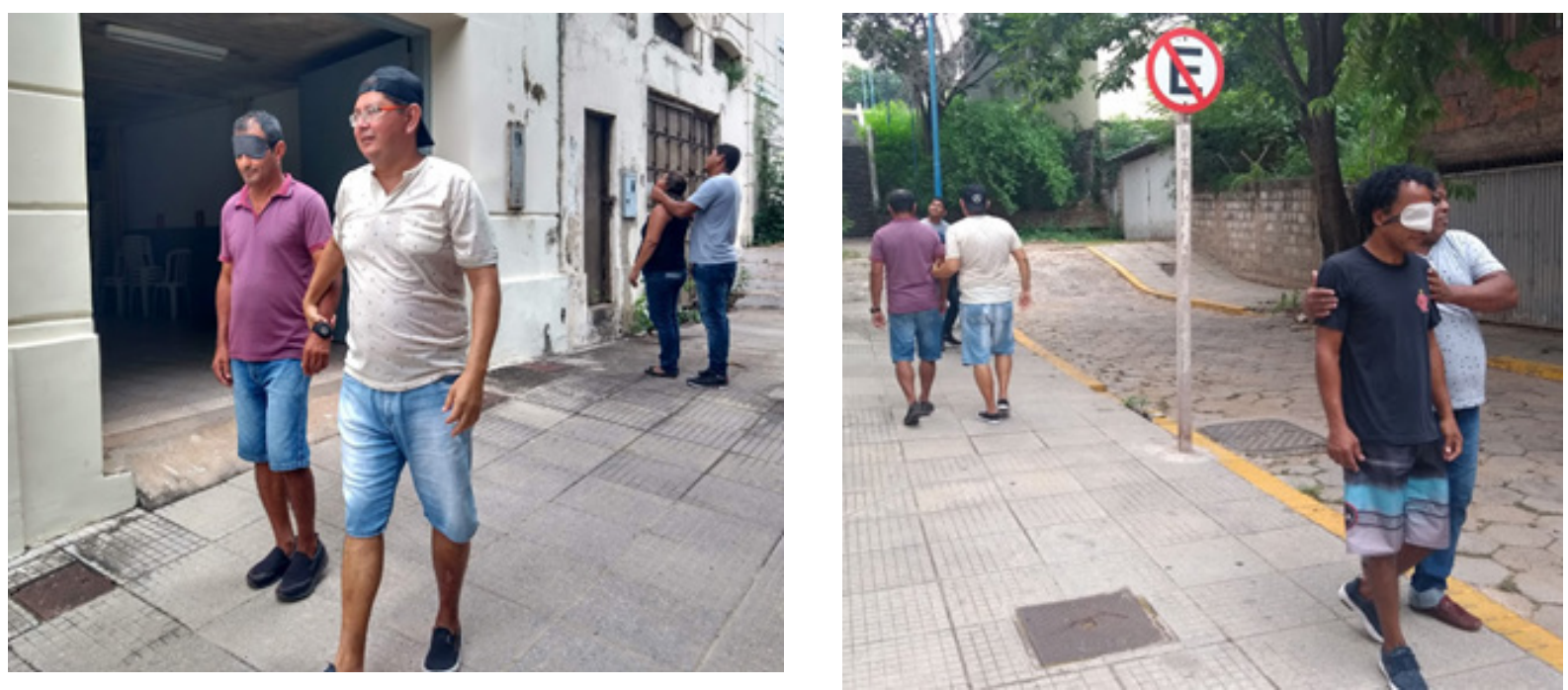

Fig. 5. Renata Americano. Máquina fotográfica e fotógrafo. Par fotográfico composto por duas fotografias da autora, 2019.

Saídas em duplas. Uma pessoa de olhos vendados, a outra como guia, conhecendo e reconhecendo o ambiente com outros sentidos que não só o da visão. Uma brincadeira de máquina fotográfica e fotógrafo. A pessoa de olhos vendados é a câmera e a outra, a guia, faz o papel de fotógrafo que procura algo para ser fotografado. Quando encontra, interrompe o andar, ajeita o ângulo da "câmera", desvenda seu parceiro e "clica". A "câmera" guarda a foto na sua memória. Cada fotógrafo tem direito a quatro fotografias para depois trocarem de lugar. No retorno, cada dupla fará um registro único da sua experiência. Na escolha do par, a ação não é apenas descrita, mas revela os modos como duas pessoas se colocam. Mãos que garantiram a segurança ao tocar os ombros ou se entrelaçarem umas nas outras. Mãos que deram insegurança. Olhares que buscaram o inusitado ou novos sentidos para os detalhes. Formas novas de olhar para o já conhecido. Uma experiência que provocou uma explosão de sentimentos e comentários: insegurança/confiança, medo/prazer, receio/vontade de me entregar, diversão/trabalho, relaxamento/tensão, descobrir/ esconder, surpresas/dissabores, alegria/tristeza.

Um novo convite: andarilhar pela cidade em busca de novos ângulos. Antes da saída para a caminhada, foi feita a proposta de buscarem novos ângulos para o olhar. Por onde eu nunca olhei? Para os detalhes? Para os outros? Para a natureza? Quais lugares da cidade em que habito eu desconheço?

Por onde nosso olhar nos leva, o corpo vai junto; gesto e olhar se completam com outros e com objetos. Olhar por um novo ângulo, mostrando lugares invisíveis ou desconhecidos. Sigamos descobrindo a cidade que parecia conhecida. As imagens acompanham os gestos do corpo que se coloca em posição de pesquisa. Um chão que salta aos olhos com suas linhas e imperfeições, que costumam desaparecer no dia a dia dos andarilhos; uma imensa árvore abraçada na experiência dos corpos que sentem sua textura, sua dimensão, sua história.

Registrar. Um momento importante da experiência e que ultrapassa o gesto 
mecânico de relatar um momento vivido, pois "pesquisar na escola significa colher, ordenar, relacionar os elementos descobertos e analisar problemas precedentes" como nos ensina Zabala (1998, p. 151). Mesas organizadas com materiais provocativos convidam para experiências com as materialidades, para ousar novas formas de registro. Tecidos, papéis, linhas, sucatas, elementos da natureza, objetos diversos compõem um cenário-convite para a construção de narrativas visuais.
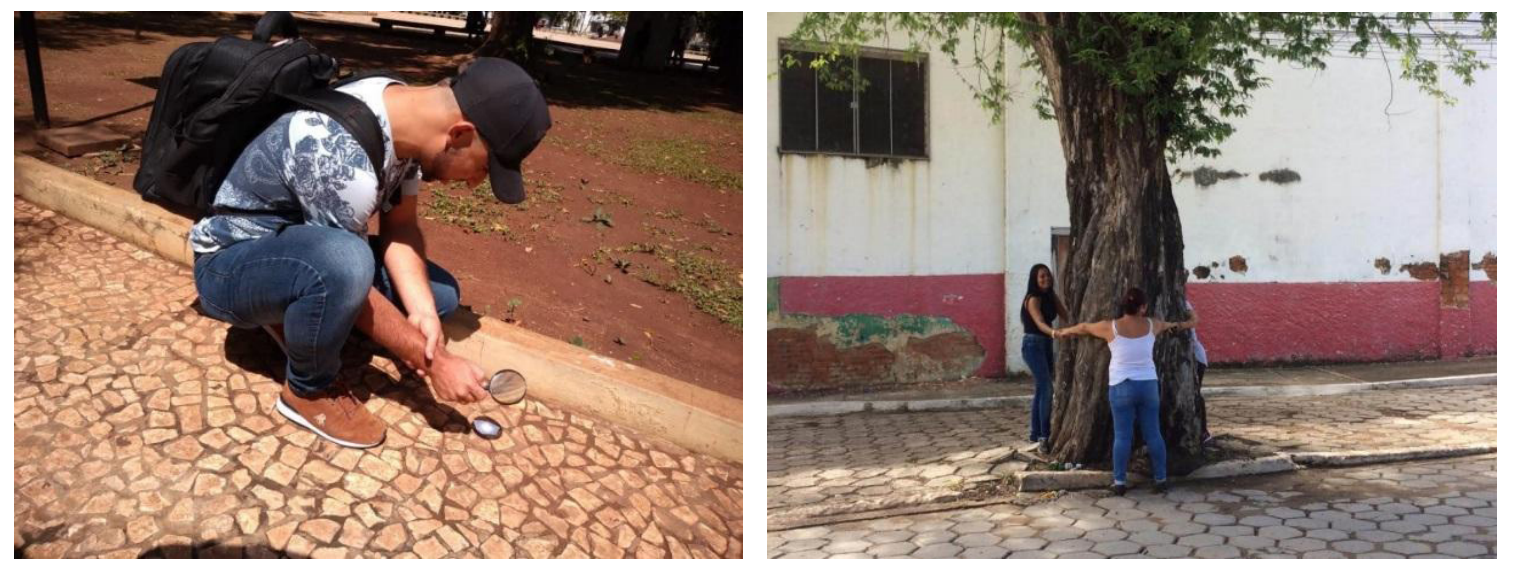

Fig. 6. Renata Americano. Olhares e ângulos. Par fotográfico composto por duas fotografias da autora, 2019.
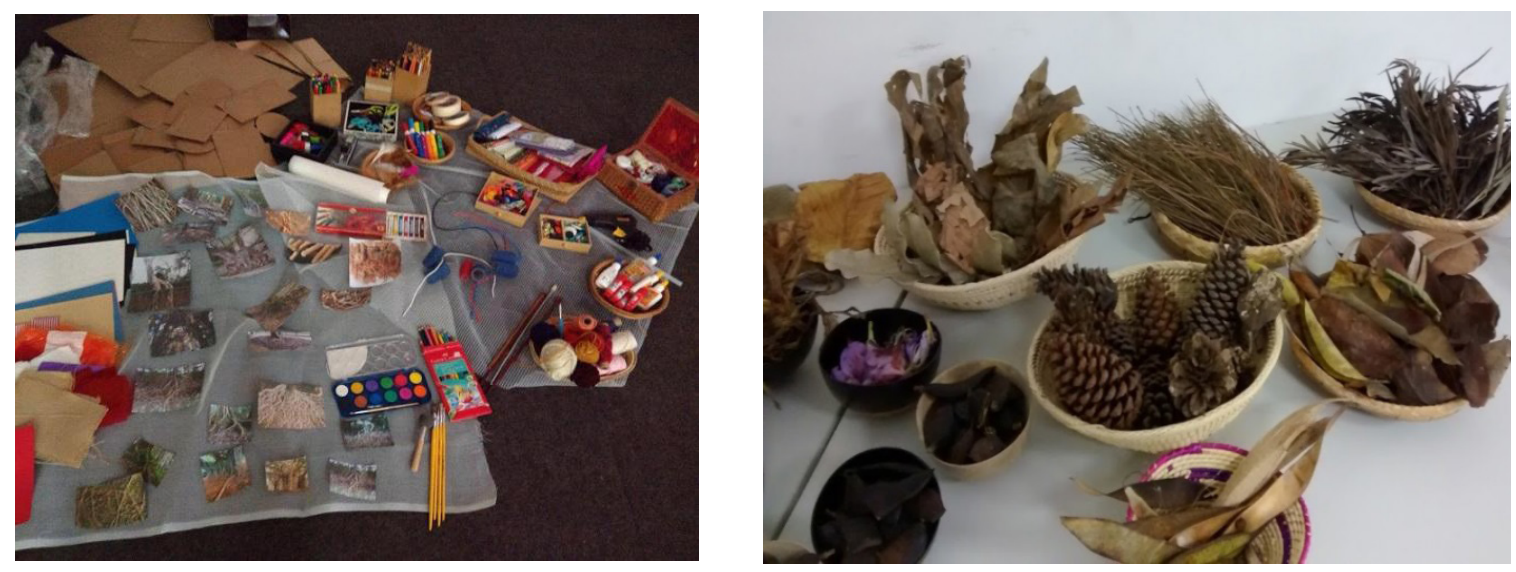

Fig. 7. Renata Americano. Banquete sensorial. Par fotográfico composto por duas fotografias da autora, 2019.

Entre inúmeras fotografias, o par fotográfico seleciona um formato nada alinhado, desconfigurado, mas, ao mesmo tempo, uma organização muito criteriosa dos materiais chama a atenção. Compor um par foi desafiante. Fez pausar o olhar nos detalhes, no contraste das cores dos materiais industrializados e no colorido sutil dos elementos da natureza. Que intenções revela a oferta do "banquete sensorial" ${ }^{5}$ ? Como os leitores destas imagens poderiam refletir sobre as ofertas de materiais

5 Banquete sensorial é um termo presente na dissertação de mestrado de: AMERICANO, Renata Queiroz de Moraes. Movimentos de desconstrução: a formação de professores e professoras / coordenadores e coordenadoras da educação básica. 2019. 105 f. Dissertação (Mestrado em Educação, 
para registro? Elas favorecem a multiplicidade de produções? A experiência pode ser única, mas nossas histórias sobre ela podem ser várias.
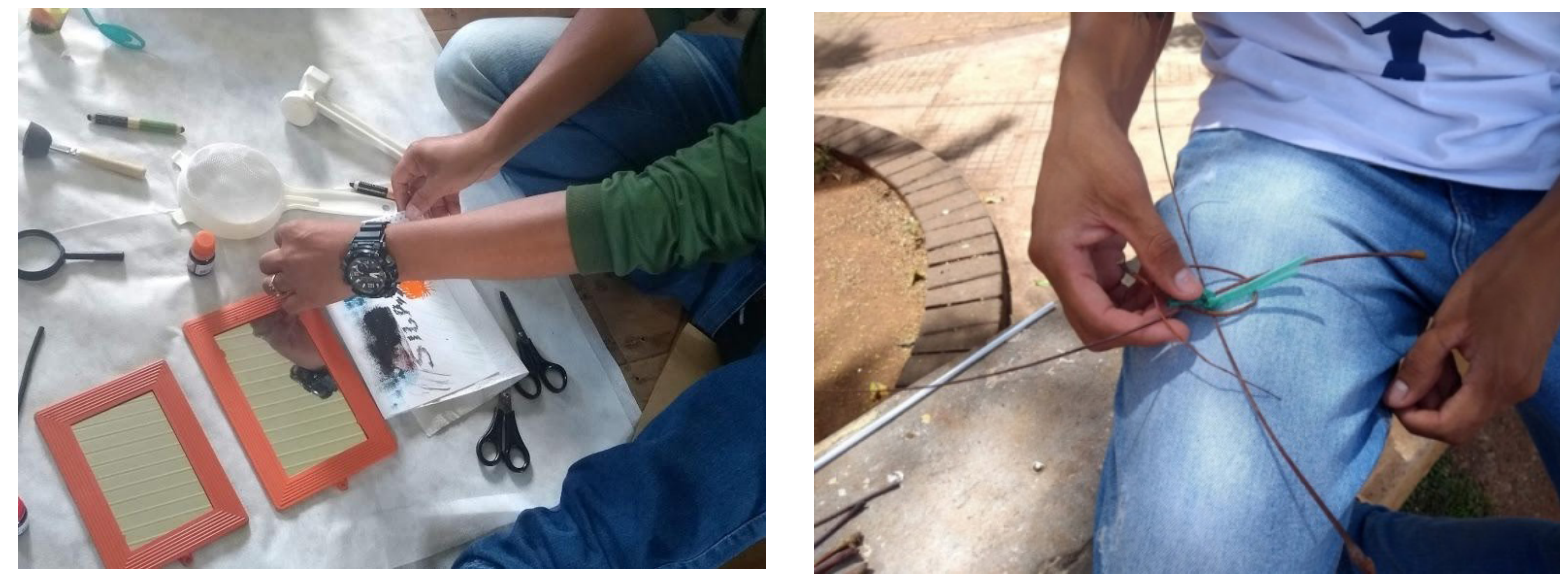

Fig. 8. Renata Americano. Formas de falar sobre o que foi sentido. Par fotográfico composto por duas fotografias da autora, 2019.

Que elementos escolho para este meu registro? Que lugar escolho para trabalhar? Que materiais vão traduzir melhor o que quero expressar? Mãos que criam, que se conectam e transformam elementos isolados em uma produção para comunicar aos outros parte da experiência. $O$ azul da calça, o close nas mãos e os gestos de criação fazem a conexão neste par fotográfico e geram uma argumentação reflexiva.

Elementos da natureza, alimentos, sucatas, fios... não importa. Queremos que cada um consiga trazer um pouco da sua experiência para uma narrativa estética, que converse com outros pelas imagens.

Ninhos, lugares de aconchego, de afetos. Verde, azul e amarelo na combinação de cores contrastam com o marrom claro dos fundos, que está sobreposto ao branco do fundo mais distante. Harmonia nas formas e nas cores. Respostas visuais de educadores criando novas relações com sua maneira de aprender e, consequentemente, de ensinar. Vivências que podem ter despertado uma transformação interna, abrindo frestas para processos de criação. As linguagens artísticas fizeram com que os indivíduos dessas ações interagissem com as novas ações que foram criadas e com as formas antigas que foram reinventadas na construção de um novo olhar para a realidade. Uma experiência única e singular.

Arte e História da Cultura) - Universidade Presbiteriana Mackenzie, São Paulo, 2019. Disponível em: http://tede.mackenzie.br/jspui/handle/tede/4015. Acesso em: 28 jun. 2021 

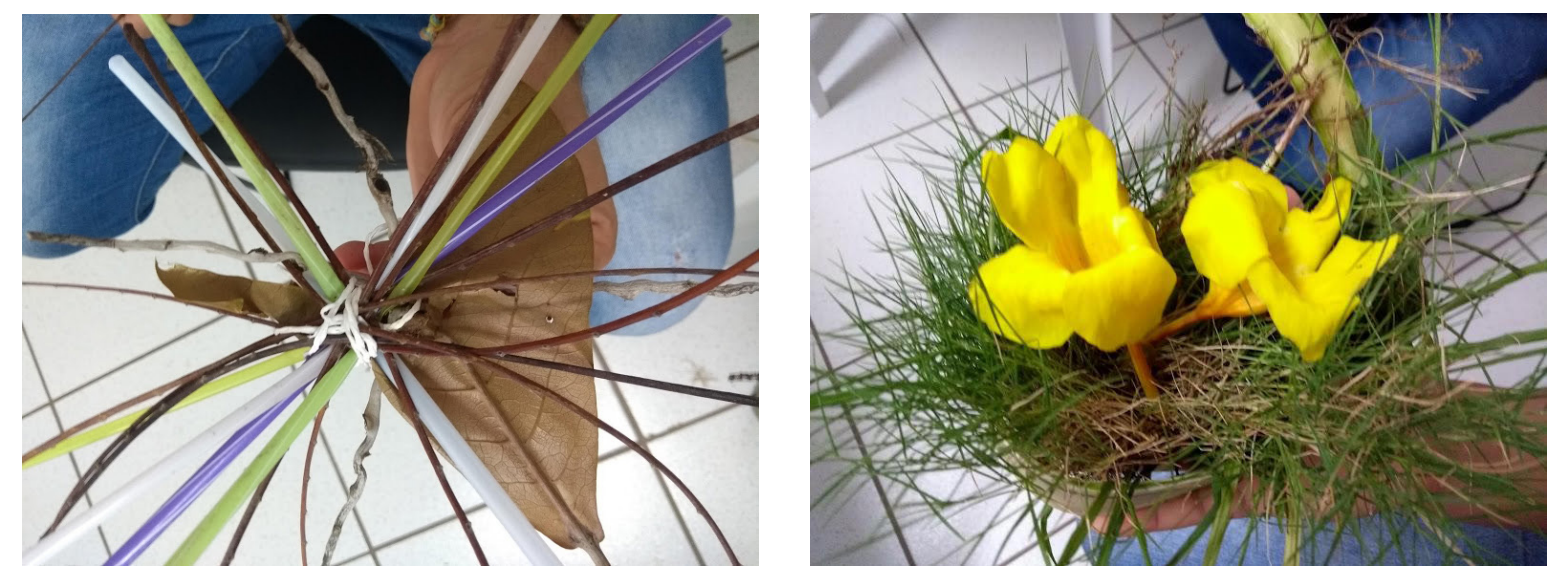

Fig. 9. Renata Americano. Natureza e registro. Par fotográfico composto por duas fotografias da autora 2019.

Ninhos, lugares de aconchego, de afetos. Verde, azul e amarelo na combinação de cores contrastam com o marrom claro dos fundos, que está sobreposto ao branco do fundo mais distante. Harmonia nas formas e nas cores. Respostas visuais de educadores criando novas relações com sua maneira de aprender e, consequentemente, de ensinar. Vivências que podem ter despertado uma transformação interna, abrindo frestas para processos de criação. As linguagens artísticas fizeram com que os indivíduos dessas ações interagissem com as novas ações que foram criadas e com as formas antigas que foram reinventadas na construção de um novo olhar para a realidade. Uma experiência única e singular.

\section{Pares fotográficos como gatilhos para a reflexão e a pesquisa}

Os pares fotográficos de Renata e Mário foram criados a partir de uma experiência docente na disciplina Leitura de imagens na formação interdisciplinar de professores do Programa de Pós-graduação em Educação, Arte e História da Cultura na Universidade Presbiteriana Mackenzie, ministrada pela terceira autora deste texto. Uma experiência que se adensa na reflexão que se conecta com as palavras de Dewey: "A reflexão não é simplesmente uma sequência, mas uma consequência - uma ordem de tal modo consecutiva que cada ideia engendra a seguinte como efeito natural e, ao mesmo tempo, apoia-se na antecessora ou a esta se refere" (1979b, p. 14). Esta consequência, entretanto, não é da ordem do espelhamento, mas da difração, como ondas que se desviam, contornam obstáculos, encontram brechas como uma sub/ versão da qualidade de uma mentoria, como apontam Rita Irwin, Natalie LeBlanc e Valerie Triggs (2019). Deste modo, a entrada neste texto possibilitou um recomeço, uma retomada da experiência vivida para ir além dele no diálogo entre nós e com os teóricos que estudamos, abrindo novas ondas e desenhos teórico-práticos que aprofundam os modos de fazer pesquisa.

Como a/r/tógrafos, criadores, professores e pesquisadores, adentramos o 
universo deweyano a partir de nossas próprias experiências docentes junto às metodologias artísticas de pesquisa. Na reflexão e na difração, a disciplina partilhada moveu os pós-graduandos por caminhos ousados e experimentais, assim como a docente da disciplina, envolvida com a leitura de cada par fotográfico e aprendendo com eles no adensamento da experiência de cria-los e lê-los.

\section{Considerações Finais}

Distintas experiências estésicas registradas com palavras e pares fotográficos se cruzaram com conceitos fundamentais encontrados em Dewey e alguns outros teóricos, tendo a a/r/tografia como metodologia de apoio.

Para projetarmos propósitos provocadores de experiências educativas, segundo Dewey (1979a, p. 67), é necessário passar por três etapas: observação do entorno, das necessidades do grupo em questão, das condições e dos contextos envolvidos na ação; conhecer o histórico de outras situações passadas; entender o que significam os indícios das observações e contextualizações de experiências passadas e fazer escolhas dos caminhos a serem seguidos. Do lugar de quem ensina, ao pensarmos em como vamos propor alguma ação, consideramos essas etapas para planejarmos nossas proposições, a fim de que sejam consistentes e tragam a possibilidade de uma experiência educativa para nossos educadores/educandos e para nós.

A pós-experiência aqui apresentada possibilitou uma revisão complexa e fundamental como modo de apropriação do vivido, ampliada pela troca entre os autores e com os pensadores que nos impulsionaram. Momento de sistematizar os afetos, perceptos e conceitos trabalhados, recorrendo a Deleuze e Guattari (1992) no aprofundamento da experiência como matéria concreta, como diria Dewey (1979a, p. 74). Matéria que ainda será ampliada no diálogo com os estudantes e com nossos leitores, gerando outras conexões e alargando aprendizagens.

Usar pares de imagem como argumentação para compor o artigo torna nossa experiência de escrita rica e ao mesmo tempo desafiadora. A linguagem visual, utilizada como forma de pesquisa, traz reflexões acerca das vivências apresentadas, mostra as perspectivas das pessoas que viveram esses momentos, sob os olhares de câmeras de celulares, e as escolhas que foram feitas acerca dos momentos que seriam registrados, postados, compartilhados. As formas como as pessoas ocupam os espaços públicos e se comportam em experiências únicas e coletivas oferecem possibilidades infinitas de leitura e estudos sobre essas vivências. E atestam sua importância. 


\section{Referências}

BRUNER, Jerome. Sobre conhecimento. Ensaios da mão esquerda. São Paulo: Phorte Editora, 2008.

CARERI, Francesco. Walkscapes: o caminhar como prática estética. São Paulo: G. Gili, 2013.

DELEUZE, Gilles e GUATTARI, Félix. O que é a Filosofia? Rio de Janeiro: Ed. 34, 1992.

DEWEY, John. Arte como experiência. São Paulo: Martins Fontes, 2010.

Experiência e educação. São Paulo: Companhia Editora Nacional, 1979a.

Vida e educação. São Paulo: Melhoramentos, 1978.

Como pensamos. São Paulo: Companhia Editora Nacional, 1979b.

IRWIN, Rita L. A/r/tografia. In: DIAS, Belidson; IRWIN, Rita L. (Orgs.). Pesquisa educacional baseada em Arte. Santa Maria: Editora da UFSM, 2013. p. 27-35.

IRWIN, Rita L.; LEBLANC, Natalie; TRIGGS, Valerie. Sub/versing Mentoring Expectations: Duration, Discernment, Diffraction. Journal of Social Theory in Art Education, v. 39, p. 8296, 2019.

LARROSA, Jorge. Tremores: escritos sobre a experiência. Belo Horizonte: Autêntica, 2015.

MIRANDA, Fernando. Imagens de arte, da ciência e da tecnologia: pesquisar a partir da cultura visual. In: MARTINS, Raimundo; TOURINHO, Irene. (orgs.). Processos e práticas de pesquisa em Cultura Visual e Educação. Santa Maria: Ed. da UFSM, 2013, p. 321-344.

SAMPAIO, Rosa Maria Whitaker Ferreira. Freinet - evolução histórica e atualidades. São Paulo: Scipione, 1989.

VIADEL, Ricardo Marín; ROLDÁN, Joaquín; GENET, Rafaèle. Pares fotográficos en investigación baseada en Artes e investigación artística. In: VIADEL, Ricardo Marín; ROLDÁN, Joaquín. (Orgs.). Investigación baseada em Artes e investigación artística. Granada: EUG, 2017.

TEIXEIRA, Anísio. Educação como reconstrução da experiência. In: DEWEY, John. Vida e educação. São Paulo: Melhoramentos, 1978.

ZABALA, Antoni. A prática educativa - Como ensinar. Porto Alegre: Artmed, 1998. 